\title{
PENERAPAN MODEL PEMBELAJARAN DISCOVERY LEARNING MENGGUNAKAN MEDIA LAB VIRTUAL PHET TERHADAP PEMAHAMAN KONSEP FISIKA
}

\author{
Ummu Kalsum, ${ }^{1, a}$, Hardi Hamzah ${ }^{2, b}$, dan Nurdia ${ }^{3, c}$ \\ ${ }_{1,2,3}$ Universitas Sulawesi Barat

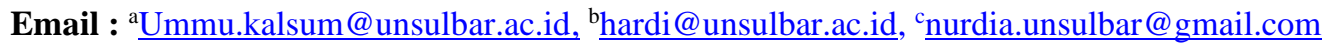

\begin{abstract}
Abstrak
Penelitian ini bertujuan untuk mengetahui perbedaan yang signifikan antara pemahaman konsep fisika peserta didik sebelum dan setelah diterapkan model pembelajaran Discovery Learning dengan menggunakan media Lab Virtual PhET. Jenis Penelitian yang digunakan adalah preeksperimen dengan bentuk desain "one-group-pretest-posttest design". Populasi penelitian meliputi seluruh peserta didik kelas X MIA SMA Negeri 1 Tinambung. Teknik pengambilan sampel dilakukan dengan purposive sampling diperoleh 26 peserta didik. Data pemahaman konsep dianalisis menggunakan analisis deskriptif dan inferensial. Berdasarkan analisis data diperoleh bahwa skor rata-rata pretest sebesar 6,19 sedangkan posttest sebesar 8,96. Hasil uji t pada taraf signifikansi 5\% menunjukkan bahwa $t_{\text {hitung }}=9,213>t_{\text {tabel }}=2,0595$. Dengan demikian dapat disimpulkan bahwa terdapat perbedaan yang signifikan antara pemahaman konsep fisika peserta didik sebelum dan setelah diterapkan model pembelajaran Discovery Learning menggunakan media Lab Virtual PhET.
\end{abstract}

Kata Kunci : Model pembelajaran Discovery Learning, Lab Virtual PhET, Pemahaman Konsep

\section{THE APPLICATION OF DISCOVERY LEARNING MODEL USING PHET VIRTUAL LAB MEDIA AGAINST THE UNDERSTANDING PHYSICS CONCEPT}

\begin{abstract}
This research was aim to knew the significant difference between students' understanding of physics concepts before and after the Discovery Learning model was applied using the Virtual Lab PhET media. This type of research was a pre-experimental research using "one-grouppretest-posttest design". The research population were all students of class X MIA SMA Negeri 1 Tinambung. The sample techniques research was taken by purposive sampling technique, as many as 26 students. The understanding of physics concepts data was analysis using descriptive and inferential analysis. Based on analysis showed that the average pretest score was 6.19 and the posttest score was 8.96 . The $t$-test at the $5 \%$ significance level showed $t_{\text {count }}=9,213>t_{\text {table }}=$ 2,0595 . Thus it can be seen that there was a significant difference between understanding the physics concepts of students before and after the learning model of Discovery Learning was applied using the Virtual Lab PhET media.
\end{abstract}

Keywords : Discovery Learning Model, Virtual Lab PhET, Concept Understanding.

\section{PENDAHULUAN}

Pada dasarnya pembelajaran dengan menggunakan kurikulum 2013 menuntun peran guru sebagai motivator dan fasilitator dalam menciptakan keaktifan peserta didik. Pemenuhan tuntutan kurikulum ini, memunculkan beberapa permasalahan 
diantaranya kurangnya perhatian dan keaktifan peserta didik terhadap materi yang diajarkan. Penyebab permasalahan ini dikarenakan teknik mengajar guru yang monoton dan minimnya penggunaan media pembelajaran. Hal ini menjadi pemicu rasa bosan dan kejenuhan peserta didik selama proses pembelajaran berlangsung.

Permasalahan yang sama ditemukan di SMA Negeri 1 Tinambung. Berdasarkan hasil wawancara dengan guru mata pelajaran fisika kelas X MIA diketahui bahwa masih terdapat banyak peserta didik yang memiliki nilai hasil belajar yang rendah. Bentuk tindak lanjut dari hasil wawancara tersebut maka diberikan tes awal berupa soal pemahaman konsep. Dari hasil tes awal diketahui bahwa $86 \%$ peserta didik kelas X memiliki nilai kurang dari nilai KKM (Kriteria Ketuntasan Minimum). Sementara untuk mata pelajaran fisika, nilai KKM yang diterapkan oleh sekolah sebesar 70. Dengan demikian, dapat disimpulkan bahwa sebagian besar peserta didik masih belum memahami konsep fisika.

Berdasarkan permasalahan diatas maka diperlukan sebuah model pembelajaran yang dapat meningkatkan pemahaman konsep peserta didik. Model pembelajaran ini haruslah mampu melibatkan peserta didik secara aktif baik secara fisik maupun mental sehingga lebih mudah memahami konsep-konsep fisika. Salah satu alternatif model pembelajaran yang dipandang cocok dengan keadaan tersebut adalah Discovery Learning. Discovery Learning adalah suatu model pembelajaran melibatkan peserta didik terjun langsung dalam kegiatan belajarmengajar sehingga mampu menggunakan proses mentalnya untuk menemukan suatu konsep atau teori yang sedang dipelajari [1]. Pada dasarnya, Discovery Learning menekankan pentingnya membantu peserta didik untuk memahami struktur atau ide-ide kunci suatu disiplin ilmu, kebutuhan akan keterlibatan aktif peserta didik dalam proses belajar, dan keyakinan bahwa pembelajaran sejati terjadi melalui penemuan pribadi, mengembangkan kemampuan dalam memecahkan masalah kehidupan sehari-hari [2].

Berikut sintaks tahapan pelaksanaan model Discovery Learning di kelas secara umum:

\section{Stimulation} rangsangan)

(stimulasi/pemberian Pada tahap ini peserta didik dihadapkan pada fenomena fisis yang menimbulkan kebingungan sehingga agar merangsang rasa ingin tahu untuk menyelidiki sendiri. Fenomena fisis disajikan dalam bentuk simulasi yang berfungsi mengembangkan dan membantu peserta didik dalam mengeksplorasi bahan.

\section{Problem statement (pernyataan/ identifikasi masalah)}

Tahap ini peserta didik diminta mengidentifikasi sebanyak mungkin masalah yang relevan dengan simulasi yang diberikan. Selanjutnya, salah satunya dipilih dan dirumuskan dalam bentuk hipotesis.

\section{Data collection (pengumpulan data)}

Tahap ini peserta didik diberi kesempatan untuk mengumpulkan (collection) berbagai informasi yang relevan, membaca literature, mengamati objek, wawancara dengan narasumber, melakukan uji coba sendiri dengan tujuan menjawab permasalahan.

\section{Data processing (pengolahan data)}

Data processing disebut juga dengan pengkodean coding/ kategorisasi yang berfungsi sebagai pembentukan konsep dan generalisasi. Data yang diperoleh selanjutnya dianalisis.

\section{Verification (pembuktian)}

Pada tahap ini peserta didik melakukan pemeriksaan secara cermat untuk membuktikan benar tidaknya hipotesis yang telah diajukan sebelumnya. Kegiatan ini tentunya dihubungkan dengan hasil data processing. 
Generalization

kesimpulan/generalisasi)

(menarik

Tahap generalisasi merupakan proses penarikan kesimpulan yang dapat dijadikan prinsip umum dan berlaku untuk semua kejadian atau masalah yang sama, dengan memperhatikan hasil verifikasi. Berdasarkan hasil verifikasi maka dirumuskan prinsip-prinsip yang mendasari generalisasi.

Pada penerapan model pembelajaran Discovery Learning di kelas tentunya membutuhkan media pembelajaran yang mampu menarik perhatian peserta didik. Salah satu media pembelajaran yang dipandang efektif untuk menunjang model pembelajaran Discovery Learning adalah lab virtual $\mathrm{PhET}$. Lab virtual merupakan laboratorium maya berbasis multimedia interaktif yang dapat mempermudah pengguna dalam melakukan eksperimen walaupun tidak berada di dalam laboratorium nyata. Kelebihan yang dimiliki adalah dapat melengkapi keterbatasan yang dimiliki oleh laboratorium nyata [3].

Media simulasi Lab virtual PhET dikemas seperti game/permainan sehingga peserta didik dapat melakukan eksploitasi materi fisika secara menyenangkan. Media ini dapat digunakan untuk memperjelas konsep-konsep fisis maupun fenomena fisika sehingga memudahkan peserta didik dalam memahami konsep fisika [4].

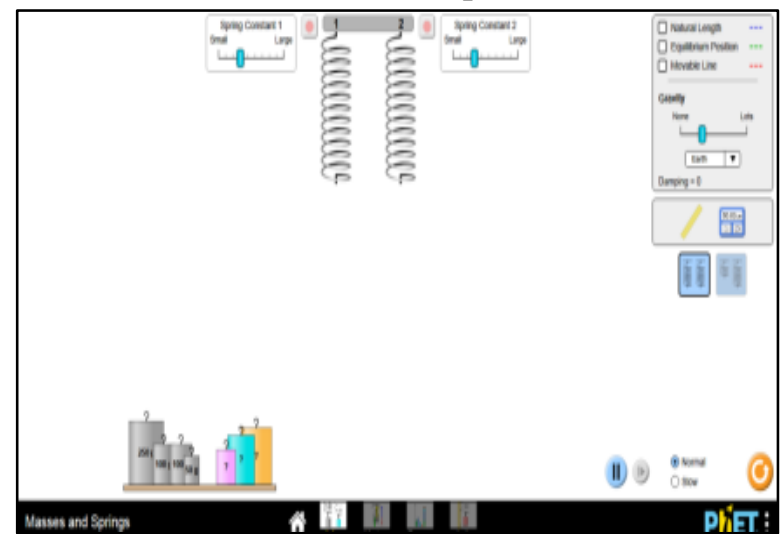

Gambar 1.Tampilan Simulasi Lab Virtual PhET pada Pokok Bahasan "masses and springs"
Pada dasarnya, pemahaman konsep merupakan kemampuan peserta didik untuk memahami suatu materi pelajaran dengan pembentukan pengetahuannya sendiri dan dapat mengungkapkan kembali dalam bentuk lain yang mudah dimengerti serta mengaplikasikannya [5].

Adapun indikator pemahaman konsep sebagai berikut [6]:

Menafsirkan (interpreting).

Indikator menafsirkan ditandai dengan kemampuan peserta didik yang dapat mengubah informasi dari satu bentuk ke bentuk lainnya, seperti mengubah kata-kata atau konsep menjadi suatu persamaan, mengubah kata-kata ke dalam bentuk gambar, grafik, dan sebaliknya.

\section{Mencontohkan (exemplifying).}

Indikator mencontohkan tercapai ketika peserta didik dapat memberikan contoh dari penerapan konsep atau prinsip umum yang telah dipelajari.

\section{Mengklasifikasikan (classifying).}

Indikator mengklasifikasikan tercapainya apabila peserta didik mampu mengelompokkan contoh maupun peristiwa ke dalam suatu kategori tertentu, seperti konsep, prinsip atau hukum tertentu.

\section{Menarik Inferensi/menyimpulkan (inferring).}

Indikator menarik inferensi ditandai dengan kemampuan peserta didik dalam menemukan pola dari sejumlah peristiwa. Penemuan pola ini dilakukan dengan mengabstraksi sebuah konsep atau prinsip yang menerangkan contoh-contoh atau kejadian-kejadian dengan mencermati ciricirinya serta mampu menarik hubungan.

\section{Membandingkan (comparing).}

Indikator membandingkan melibatkan proses mendeteksi persamaan dan perbedaan antara dua atau lebih objek, peristiwa, ide, masalah, atau situasi, seperti menentukan bagaimana suatu peristiwa terkenal menyerupai peristiwa yang kurang terkenal. 
Menjelaskan (explaining).

Indikator menjelaskan berlangsung ketika peserta didik dapat membuat dan menggunakan model sebab-akibat dalam sebuah sistem.

Lebih jauh kajian mengenai pemahaman konsep dengan menerapkan model Discovery Learning dilakukan oleh Siti Mawaddah dan Ratih Maryanti pada tahun 2015 yang mengatakan bahwa pemahaman konsep peserta didik dengan menggunakan model pembelajaran Discovery Learning secara keseluruhan pada kategori baik dan respon peserta didik cenderung setuju [7]. Model pembelajaran Discovery Learning dengan bantuan media simulasi PhET dapat menciptakan suasana pembelajaran yang menarik dan mampu menumbuhkan peran aktif peserta didik [8].

\section{METODE}

\section{Lokasi dan Waktu Penelitian}

Penelitian ini telah dilaksanakan di SMA Negeri 1 Tinambung yang beralamat di Jl. Poros Polman Majene, Balanipa, Kabupaten Polman, Sulawesi Barat. Penelitian ini berlangsung selama 6 kali pertemuan pada semester genap tahun pelajaran 2018/2019.

\section{Desain Penelitian}

Penelitian ini merupakan penelitian pre-eksperimen dengan menggunakan desain "One Group Pretest-Posttest design"

$\begin{array}{lll}\mathbf{O}_{1} & \mathbf{X} & \mathbf{O}_{2}\end{array}$

\section{Populasi dan Sampel}

Populasi dalam penelitian ini meliputi seluruh peserta didik kelas X MIA SMA Negeri 1 Tinambung tahun pelajaran 2018/2019 dengan jumlah peserta didik yaitu 181 orang. Sampel yang digunakan yaitu kelas X MIA 5 sebanyak 26 orang. Teknik sampling yang digunakan yaitu purposive sampling dengan pertimbangan tertentu.

\section{Prosedur Penelitian}

Tahap persiapan

a. Berkonsultasi dengan Kepala sekolah SMA Negeri 1 Tinambung selaku pimpinan Satuan Pendidikan guna meminta izin melakukan penelitian.

b. Berkonsultasi dengan guru bidang studi Fisika kelas $\mathrm{X}$ untuk melakukan wawancara dan kegiatan observasi.

c. Membuat rencana pelaksanaan pembelajaran (RPP)

d. Menyusun instrumen penelitian berupa tes pemahaman konsep dalam bentuk tes pilihan ganda beralasan.

e. Memvalidasi instrumen penelitian sebelum digunakan dalam pengambilan data pemahaman konsep fisika

f. Menyiapkan media pembelajaran berupa Lab Virtual PhET.

Tahap pelaksanaan penelitian

a. Memberikan tes awal (pretest) berupa tes pemahaman konsep

b. Melaksanakan proses belajar dengan menerapkan model pembelajaran Discovery Learning dengan menggunakan media Lab Virtual PhET.

c. Memberikan tes akhir (post-test) berupa tes pemahaman konsep

\section{Tahap Akhir}

a. Melakukan analisis dan evaluasi terhadap pelaksanaan dan hasil penelitian.

b. Menyusun laporan penelitian

\section{Teknik Analisis Data}

Teknik analisis yang digunakan dalam penelitian ini adalah analisis statistik deskriptif dan analisis inferensial.

\section{Analisis Deskriptif}

Persamaan matematis yang digunakan dalam analisis deskriptif untuk penelitian ini terdiri atas :

Menghitung rata-rata $(\underline{X})$ 


$$
\underline{x}=\frac{\sum f i x_{i}}{f_{i}}
$$

\section{Standar deviasi (s)}

$$
s=\sqrt{\frac{\sum f X^{2}}{n}-\left(\frac{\sum f X}{n}\right)^{2}}
$$

\section{Menghitung Nilai}

Pengubahan skor pemahaman konsep fisika ke bentuk nilai dihitung dengan menggunakan rumus sebagai berikut :

$$
\text { Nilai }=\frac{\text { skor mentah }}{\text { skor maksimum ideal }} \times 100 \ldots(4)
$$

Adapun kriteria penilaian tingkat pemahaman konsep peserta didik sebagai berikut:

Tabel 1. Interpretasi Kemampuan Pemahaman Konsep

\begin{tabular}{cc}
\hline Interval & Kriteria \\
\hline $81-100$ & Sangat Tinggi \\
$61-80$ & Tinggi \\
$41-60$ & Sedang \\
$21-40$ & Rendah \\
$0-20$ & Sangat Rendah \\
\hline
\end{tabular}

\section{Analisis Inferensial}

\section{Uji normalitas data}

Pengujian normalitas bertujuan untuk mengetahui apakah data yang diperoleh berasal dari responden berdistribusi normal atau tidak. Pengujian ini dilakukan dengan menggunakan persamaan sebagai berikut:

$$
\chi^{2}=\frac{\sum \quad\left(O_{i}-E_{i}\right)^{2}}{E_{i}}
$$

\section{Uji hipotesis}

Pengujian hipotesis yang digunakan dalam penelitian ini adalah uji-t, dengan $\alpha=$ 0,05. Rumus uji-t sebagai berikut:

$$
t=\frac{\underline{D}}{S_{D}}
$$

Syarat pengujian hipotesis :

$>$ Jika $t_{\text {hitung }}>t_{\text {tabel }}$, maka $\mathrm{H}_{0}$ ditolak dan $\mathrm{H}_{1}$ diterima

$>$ Jika $\mathrm{t}_{\text {hitung }}<\mathrm{t}_{\text {tabel }}$, maka $\mathrm{H}_{1}$ ditolak dan $\mathrm{H}_{0}$ diterima

Adapun Bentuk Hipotesis :

$$
\begin{aligned}
& \mathrm{H}_{0}: \mu=\mu_{0} \\
& \mathrm{H}_{\mathrm{i}}: \mu \neq \mu_{0}
\end{aligned}
$$

Keterangan :

$\mu_{0}$ : Rata-rata pemahaman konsep fisika peserta didik sebelum diterapkan model pembelajaran Discovery Learning dengan menggunakan media lab virtual PhET (Physics Education Technology).

$\mu$ : Rata-rata pemahaman konsep fisika peserta didik setelah diterapkan model Discovery Learning dengan menggunakan media lab virtual $\mathrm{PhET}$ (Physics Education Technology).

\section{HASIL DAN DISKUSI}

\section{Analisis Deskriptif}

Berikut ini dikemukakan hasil analisis deskriptif pemahaman konsep fisika peserta didik kelas X MIA sebelum dan setelah diajar dengan model pembelajaran Discovery Learning menggunakan media Lab Virtual PhET.

Tabel 2. Hasil Pemahaman Konsep Peserta

\begin{tabular}{ccc}
\multicolumn{3}{c}{ Didik } \\
\hline Skor & Pretest & Posttest \\
\hline Skor tertinggi & 10 & 13 \\
Skor terendah & 2 & 5 \\
Skor ideal & 15 & 15 \\
Rata-rata & 6.19 & 8.96 \\
Standar Deviasi & 2.58 & 2.39 \\
\hline
\end{tabular}

Berdasarkan tabel 2 diketahui bahwa terdapat perbedaan nilai rata-rata pemahaman konsep sebelum dan setelah diajar diberikan perlakuan. Rata-rata pemahaman konsep posttest lebih besar dibandingkan data pretest. Hal ini menunjukkan bahwa terdapat peningkatan pemahaman konsep fisika peserta didik setelah diajar dengan model pembelajaran 
Discovery Learning menggunakan media Lab Virtual PhET.

Untuk mengetahui gambaran lebih jelas mengenai data pretest, dapat dilihat pada tabel 3 berikut:

Tabel 3 Kategori Tingkat Pemahaman

Konsep Fisika untuk data pretest.

\begin{tabular}{cccc}
\hline No & $\begin{array}{c}\text { Interval } \\
\text { Nilai }\end{array}$ & Kategori & Frekuensi \\
\hline 1 & $0-20$ & Sangat rendah & 6 \\
2 & $21-40$ & Rendah & 9 \\
3 & $41-60$ & Sedang & 8 \\
4 & $61-80$ & Tinggi & 3 \\
5 & $81-100$ & Sangat tinggi & 0 \\
\hline
\end{tabular}

Berdasarkan tabel 3 diatas diketahui bahwa sebagian besar pemahaman konsep peserta didik sebelum diberikan perlakuan berada pada kategori rendah dengan frekuensi sebanyak 9 orang. Sementara untuk data posttest menunjukkan hasil sebagai berikut :

Tabel 4 kategori tingkat pemahaman konsep fisika untuk data posttest

\begin{tabular}{cccc}
\hline No. & $\begin{array}{c}\text { Interval } \\
\text { kelas }\end{array}$ & Kategori & $\begin{array}{c}\text { Frek } \\
\text { uensi }\end{array}$ \\
\hline 1 & $0-20$ & Sangat rendah & 0 \\
2 & $21-40$ & Rendah & 4 \\
3 & $41-60$ & Sedang & 12 \\
4 & $61-80$ & Tinggi & 8 \\
5 & $81-100$ & Sangat tinggi & 2 \\
\hline
\end{tabular}

Berdasarkan tabel 4 diatas diketahui bahwa sebagian besar pemahaman konsep peserta didik setelah diajar dengan model pembelajaran Discovery Learning menggunakan media Lab Virtual PhET berada pada kategori sedang dengan frekuensi sebanyak 12 orang.
Jika data pretest dan posttest dibandingkan untuk setiap kategori maka diperoleh gambaran sebagai berikut :

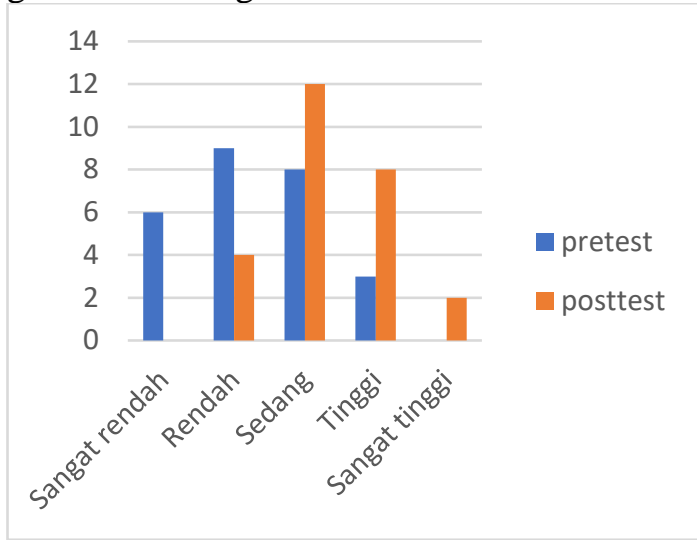

Gambar 2. Grafik perbandingan pretest dan posttest untuk kategori yang sama.

Berdasarkan gambar 2 diketahui bahwa terdapat peningkatan frekuensi pada kategori sedang, tinggi dan sangat tinggi untuk data posttest. Sementara pada kategori rendah terjadi penurunan frekuensi. Hal ini berarti bahwa terjadi peningkatan data posttest dibandingkan data pretest.

\section{Analisis Inferensial Uji Normalitas}

Hasil pengujian normalitas data pretest menunjukkan nilai $X_{\text {hitung }}^{2}=5,878$ dan data posttest $X_{\text {hitung }}^{2}=2,560$ dengan $X_{\text {tabel }}^{2}=11,070$ pada taraf signifikansi $\alpha=$ 0,05 dan $\mathrm{dk}=5$. Karena $X_{\text {hitung }}^{2}<X_{\text {tabel }}^{2}$ maka data pemahaman konsep fisika peserta didik untuk pretest dan posttest berasal dari populasi yang berdistribusi normal

\section{Pengujian Hipotesis}

Hasil uji $\mathrm{t}$ menunjukkan $\mathrm{t}_{\text {hitung }}=9,213$ sedangkan $t_{\text {tabel }}=2,0595$ pada taraf nyata $\alpha$ $=0,05$ dengan $\mathrm{v}=25$. Karena $\mathrm{t}_{\text {hitung }}>\mathrm{t}_{\text {tabel }}$ maka $\mathrm{H}_{0}$ ditolak dan $\mathrm{H}_{\mathrm{a}}$ diterima. Hal ini berarti bahwa terdapat perbedaan yang signifikan antara pemahaman konsep fisika peserta didik kelas X MIA SMA Negeri 1 Tinambung sebelum dan setelah diterapkan model pembelajaran Discovery Learning dengan menggunakan media Lab Virtual PhET. 
Hasil pretest menunjukkan bahwa dari 26 peserta didik yang menjadi sampel diperoleh skor rata-rata pada pemahaman konsep sebesar 6,192 dengan standar deviasi 2,58. Berdasarkan tinjauan frekuensi pada tabel 4.2 maka frekuensi terbesar berada pada kategori rendah. Hasil ini bermakna bahwa pemahaman konsep fisika peserta didik sebelum diterapkan model pembelajaran Discovery Learning menggunakan media Lab Virtual PhET berapa pada kategori rendah.

Rendahnya pemahaman konsep peserta didik disebabkan oleh beberapa factor diantaranya : (1). Kurangnya minat peserta didik terhadap mata pelajaran fisika. Hal tersebut didukung oleh cara mengajar guru yang monoton, sehingga peserta didik merasa bosan,(2) Minimnya latihan dalam mengerjakan soal berbasis pemahaman konsep sehingga membuat peserta didik kesulitan dan kaku ketika berhadapan dengan soal selain yang diajarkan gurunya. Selama ini soal yang diajarkan hanya berada pada tataran C3. (3) Minimnya penggunaan media pembelajaran fisika sehingga tidak ada rangsangan yang mampu menarik perhatian peserta didik terhadap materi yang diajarkan.

Selanjutnya, setelah menerapkan model pembelajaran Discovery Learning menggunakan media Lab Virtual PhET diperoleh hasil posttest dengan skor ratarata 8,96. Berdasarkan tinjauan frekuensi maka frekuensi maksimum berada pada kategori sedang. Hal ini berarti bahwa pemahaman konsep fisika setelah diterapkan model pembelajaran Discovery Learning menggunakan media Lab Virtual PhET berada pada kategori sedang.

Sekalipun secara akumulatif hanya mengalami peningkatan satu kategori dari rendah ke kategori sedang. Namun, terjadi peningkatan frekuensi pada kategori tinggi dan sangat tinggi. Adanya peningkatan data posttest dan pretest disebabkan oleh tahapan dalam sintaks model pembelajaran Discovery Learning mampu menumbuhkan peran aktif peserta didik untuk terlibat langsung dalam pembelajaran. Pengalaman belajar yang diperoleh mulai dari tahapan stimulasi, identifikasi masalah, pengumpulan data, pengolahan data, pembuktian hipotesis hingga pada tahapan generalisasi mampu menemukan dan membuktikan konsep-konsep fisika yang sudah ada.

Kehadiran media Lab Virtual PhET mampu menarik perhatian peserta didik untuk fokus pada pembelajaran. Media ini merupakan sesuatu yang baru bagi peserta didik sehingga mengundang rasa ingin tahu untuk mahir menggunakan Lab Virtual $\mathrm{PhET}$. Hal ini terlihat dari antusias peserta didik menggunakan Lab Virtual PhET pada setiap kelompok kerja. Fungsi dari Lab Virtual PhET sendiri membantu peserta didik untuk memudahkan dalam memahami konsep fisika. Tentunya hal ini berdampak pada peningkatan pemahaman konsep peserta didik. Pernyataan ini didukung oleh hasil penelitian $P$ Sinaga yang menyimpulkan bahwa pembelajaran dengan media Lab Virtual mampu meningkatkan pemahaman konsep fisika peserta didik.

Berdasarkan perbandingan hasil pretest dan posttest diperoleh informasi bahwa terdapat peningkatan pemahaman konsep fisika peserta didik sebelum dan setelah diterapkan model pembelajaran Discovery Learning menggunakan media Lab Virtual PhET. Pernyataan ini didukung oleh hasil analisis inferensial menggunakan uji $\mathrm{t}$ dengan capaian $\mathrm{t}_{\text {hitung }}=9,213>\mathrm{t}_{\text {tabel }}=$ 2,0595. Hal ini berarti $\mathrm{H}_{0}$ ditolak dan $H_{i}$ diterima. Dengan demikian dapat disimpulkan terdapat perbedaan yang signifikan antara pemahaman konsep fisika kelas X MIA 5 SMA Negeri 1 Tinambung sebelum dan setelah diterapkan model pembelajaran Discovery Learning dengan menggunakan media Lab Virtual PhET. 
Adanya perubahan pemahaman konsep fisika peserta didik setelah diajar dengan model pembelajaran Discovery Learning menggunakan media Lab Virtual PhET sejalan dengan penelitian yang dilakukan oleh Hamidah Lidiana dkk (2018). Hasil penelitiannya mengungkapkan bahwa model pembelajaran Discovery Learning berbantuan paket program simulasi PhET sangatlah cocok digunakan dalam pembelajaran fisika karena dapat menciptakan suasana belajar yang menarik dan membuat peserta didik lebih aktif.

\section{SIMPULAN DAN SARAN}

Simpulan

Berdasarkan hasil penelitian dapat disimpulkan bahwa terdapat perbedaan yang signifikan antara pemahaman konsep fisika peserta didik kelas X MIA SMA Negeri 1 Tinambung sebelum dan setelah diterapkan model pembelajaran Discovery Learning dengan menggunakan media Lab Virtual PhET .

\section{Saran}

Efektifitas kerja kelompok perlu ditingkatkan sehingga tidak hanya sebagian peserta didik yang mendominasi kerja tim. Bagi peneliti yang tertarik melakukan topik serupa dapat menambahkan variabel moderator seperti minat belajar dan aktivitas peserta didik dalam pembelajaran.

\section{DAFTAR PUSTAKA}

[1] Suminar, Serra Oktafoura. 2016. Pengaruh Model Pembelajaran Discovery Learning dan Problem Based Learning Terhadap Prestasi Belajar Peserta Didik. Bandung: Jurnal Pendidikan Manajenen Perkantoran. Vol. 1. No. 1. Hal. 8493.

[2] Fitri, Marisa dan Derlina. 2015. Pengaruh Model Pembelajaran
Discovery Learning Terhadap Hasil Belajar Peserta didik Pada Materi Pokok Suhu dan Kalor. Jurnal Inpafi. Vol 3. No 2. Hal 89-96.

[3] Syaifulloh, Rizal Bagus., Jatmiko, Budi 2014. Penerapan Pembelajaran Dengan Model Guided Discovery Dengan Lab Virtual PhET Untuk Meningkatkan Hasil Belajar Siswa Kelas XI Di SMAN 1 Tuban Pada Pokok Bahasan Teori Kinetik Gas. Surabaya: Jurnal Inovasi Pendidikan Fisika. ISSN: 2302-4496. Vol. 03. No.02.Hal.174-179.

[4] Sari, Dyah Permata., Lutfi, Ahmad., \& Qosyim, Ahmad. 2013. Uji Coba Pembelajaran IPA dengan LKS Sebagai Penunjang Media Virtual Phet Untuk Melatih Keterampilan Proses Pada Materi Hukum Archimedes. Jurnal Pendidikan Sains e-Pensa. Vol 01. Nomor 02. Hal 1520.

[5] Septiani, Nicke. 2014. Pengaruh Penerapan Pendekatan Scaffolding Terhadap Kemampuan Pemahaman Konsep Matematika Siswa Kelas Viii Smp Pertiwi 2 Padan. Jurnal Pendidikan Matematika. Vol 3. No 3. Hal 17-21.

[6] Irwandani. 2015. Pengaruh model pembelajaran generative terhadap pemahaman konsep pokok bahasan bunyi peserta didik mts al-hikmah Bandar lampung. Jurnal pendidikan fisika Al- BIRUNI. Vol 04. No 2. Hal 165-177.

[7] Mawaddah, Siti. 2016 Kemampuan

Pemahaman Konsep Matematis Peserta didik SMP dalam Pembelajaran Menggunakan Model Penemuan Terbimbing (Discovery Learning). Banjarmasin: Jurnal Pendidikan Matematika. Vol 4. No 1. Hal. 76-85. 
[8] Hariyanto, Agus. 2016. Pengaruh Discovery Learning Berbantuan Paket Program Simulasi Phet Terhadap Prestasi Belajar Fisika. Jurnal Pendidikan dan Kebudayaan. Vol.1 No 3. Hal 365-378.

[9] Sugiono. 2017. Metode Penelitian Pendidikan Pendekatan Kuantitatif Kualitatif $R \& D$. Bandung: Alfabeta

[10] Susetyo, Budi. 2017. Statistika untuk analisis data penelitian dilengkapi cara perhitungan dengan SPSS dan MS Office Excel. Bandung: PT Refika Aditama.

[11] Susetyo, Budi. 2015. Statistika untuk analisis data penelitian dilengkapi cara perhitungan dengan SPSS dan MS Office Excel. Bandung: PT Refika Aditama.

[12] Majid, Abdul. 2016. Strategi Pembelajaran. Bandung: PT. Remaja Rosdakarya.

[13] Maesyarah. 2015. Analisis Penguasaan Konsep dan Miskonsepsi Biologi dengan Teknik Modifikasi Certainy of Respons Index pada peserta didik SMP Se-Kota Sumbawa Besar. Jurnal Pijar MIPA. Vol X. No 1. Hal 1-6 